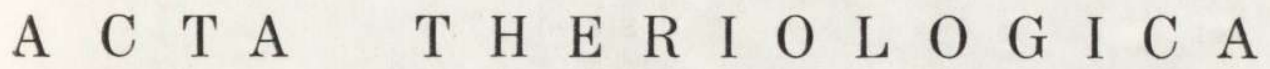 \\ VOL. $18,23: 443-458$. \\ BIAEOWIEŻA \\ December, 1973
}

\author{
Uolevi SKARÉN
}

\section{Spring Moult and Onset of the Breeding Season of the Common Shrew (Sorex araneus L.) in Central Finland}

\author{
[With 6 Tables \& 5 Figs.]
}

\begin{abstract}
The material, 764 individuals, was collected in Central Finland in winter and in spring. The moulting of the common shrew is here a complicated phenomenon that lasts about two months and seems to be at least partly in connexion with sexual hormones. The males begin to moult before the thermal spring, in late March - early April. In a few days they get the spring fur and mature. The moult is fairly often interrupted to "rest stage", the cause of which is not known. The amount of such individuals vary during different years. The spring fur is changed to summer fur only two months later, when the thermal summer comes. The females seldom have spring moult I. Normally their winter fur changes directly to summer fur, which does not take place until late April - early May. They get summer fur 2-3 weeks before the males and also have rest stages fairly often. The spring moult of females is in connexion with pregnancy: it is over in good time before the first parturition. The size of the first litter was the same as in Western and Central Europe, but the second one was a little larger. Sex ratio was $1: 1$ in winter and in early summer (subadults). However, in overwintered animals more males were caught during the whole spring except in late May, when the ratio is again $1: 1$.
\end{abstract}

\section{INTRODUCTION}

The complicated moult of the common shrew, Sorex aranaus $\mathrm{L}$ in$\mathrm{n}$ a e u s, 1758 has been explained in many ways (O g n e v, 1928; B orowski, 1952; Spannhof, 1952; S tein, 1954; Crowcroft, 1957; B a u er, 1960; S k a r é n, 1964, and others). Most authors believe that there are two moults, one in autumn, the other in spring. Some authors (Ognev, 1928; Stein, 1954) mention a third, summer moult, too.

It was Borowski who (1968) began to clear up this question. In this study Borowski's results have been compared with the Finnish material, because there may be differences in different climatological conditions. Moreover, it is possible that the sibling species of Sorex araneus (M e y l a n, 1965; Fr e d g a, 1973) differ from each other in this respect. 
In this study special attention has been given to the fact that mouit is in connexion with certain phenomena of the reproduction period; as a rule the authors have passed over this question or only mentioned it (e.g. $\mathrm{S}$ te in, 1954), although the reproduction of this species has been much studied especially in Central Europe (M iddlet on, 1931; B r a mbell, 1935; Borowski \& Dehnel, 1952; Wolska, 1952; Crowcroft, 1957; Tarkowski, 1957; Pucek, 1959; B a uer, 1960; S te in, 1938, 1961, and others).

Also the growth of the body is in connexion with both moult and maturation. It seemed reasonable to examine these phenomena in the same small area, because the material from e.g. the whole of Finland (S i i v on e n, 1954) may be too scattered.

\section{MATERIAL AND METHODS}

In $1964-1972$ in winter and in spring (1.XI-15.V) 764 individuals were trapped in Iisalmi, Central Finland $\left(63^{\circ} 30^{\prime}\right.$ N.L., $27^{\circ}$ E.L.). For various reasons it was noi possible to get all data from all individuals.

Trapping was done with small commercial snap-traps baited with cheese and arranged in irregular lines, usually $4-5$ metres apart.

All individuals are preserved as skulls, many as skins and some are in formalin.

The weight of females include the embryos and the milk glandular tissue, which may weigh even $2 \mathrm{~g}$.

The males with $5 \mathrm{~mm}$ long testes were regarded as mature because (a) descensus testiculorum begins then and (b) such testes weigh together over $50 \mathrm{mg}$, so (according to $\mathrm{Brambe} 11,1935)$ there are spermatozoa in them.

The females were regarded as mature when embryos or milk glandular tissue were visible.

The different kinds of fur were defined according to the length of the hair and the number of segments in it. These segments can be clearly seen with a microscope, but often (especially on the belly side) they may be counted with the naked eye, because the strictures between them reflect light differently. The hair sample was taken $2 \mathrm{~cm}$ from the base of the tail on the medial line of the upper and under side of the animal. On the belly side the length of the hair does not vary much, but on the rump it is important always to measure it just on the same place, because the fur is longest on the base of the tail and shortens then cranially; it may shorten $2 \mathrm{~mm}$ within $2 \mathrm{~cm}$, which is enough to mix up e.g. the winter and spring fur.

The material was collected mainly at the edge of cultivations (Alnus incana, Betula verrucosa, Salix sp., Rubus idaeus, sparsely Carex sp. and Deschampsia caespitosa) or on the shore of eutrofic lakes. The latter may be the optimum habitat of Sorex araneus; there are bushes of birches and villows, a lot of hummocks of Carex rostrata, C. vesicaria and Deschampsia caespitosa, and Scirpus silvaticus here and there. Insects and spiders are common and even on hot days it is moist and cool between the hummocks, where even small lumbricids may be seen on the paths of the shrews at noon. 
The climatic conditions of the study area. The following statistics are based on meteorological observations in Kuopio (75 km south of Iisalmi), Vieremä and Kajaani (75 km north of Iisalmi) (A. O k s a, in litt.).

The deepest snow cover (on an average $60 \mathrm{~cm}$ ) is 20.III. The snow has melted away about 1.V. (Kuopio) and 5.V. (Kajaani). The insulating power of the snow is good: the temperature $20 \mathrm{~cm}$ deep in the soil is always about $0^{\circ} \mathrm{C}$ in midwinter.

Frost in the night is common in April and often occurs as late as the end of May.

The meteorological spring (the mean temperature of day and night exceeds $0^{\circ} \mathrm{C}$ ) begins 11.IV in Kuopio and 14.IV in Kajaani, the summer (the mean temperature over $+10^{\circ} \mathrm{C}$ ) respectively 26 . and 30 .V. The springs in the study area have been long and unsteady with alternating cold and warm periods.

\section{FUR TYPES}

The following fur types were assorted:

Winter fur. Back dark brown, belly, grey and almost always a little darker than in the spring fur. There is at least a weak brown

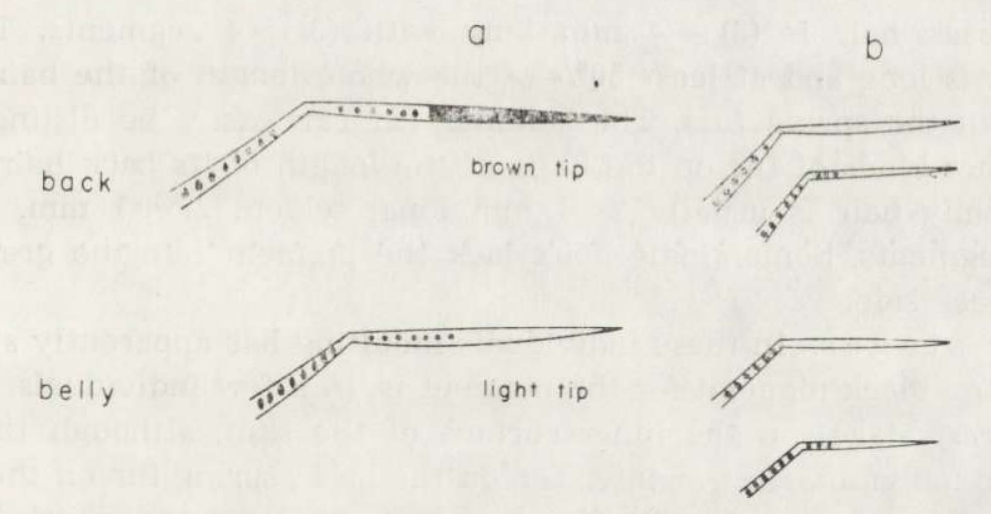

Fig. 1. Different types of tips of hair. Magn. $50 \times$. a) long, b) short tip segment.

side-zone between the back and belly, even if the paleness and the breadth of this zone are variable. Two-coloured animals with no side-zone were not trapped; such individuals live at least in Northern Lapland (S k a r é $\mathrm{n}, 1964)$.

The back hair is usually $8 \mathrm{~mm}(7-8.5 \mathrm{~mm})$ long with $7(6-8)$ segments. Respectively the length of a belly hair is $4+1 \mathrm{~mm}$, seldom $3.5+1 \mathrm{~mm}$ ( $1 \mathrm{~mm}=$ the light tip of the hair) and there are usually 5 (4-6) segments.

Two kinds of tips can be found in the hair of the winter fur (and other fur types, too); the tip segment is long and partly pigmented or short and usually with no pigment cells (Fig. 1); the latter type is rarer. 
Spring fur. Back dark brown as in winter, with a light brown side-zone, but on an average it may be a little darker and broader than in wirter. The clearest difference is on the belly side which is always lighter, pale grey.

The back hair is $6 \mathrm{~mm}(5-6.5 \mathrm{~mm})$ long with $5(4-6)$ segments. The tip segment contains less than $50 \%$ of the whole length of the hair (compare with summer fur). The belly hair is $4 \mathrm{~mm}(3.5-4.5 \mathrm{~mm}$ ) long including a $1-1.5 \mathrm{~mm}$ long light tip and usually 4 (long tip segment) or 5 (short tip segment) segments. Grey hairs without pigment may aiready be seen on the back.

Summer fur of old adult. This seems to be the darkest fur especially concerning the females: back and belly are perhaps a littie darker, but the difference is clearest on the side-zone, which is now, on an average, at its broadest and darkest. The darkness of this zone somewhat varies, but the three colours (back, side-zone, belly) were always visible; dark one-coloured individuals (Sorex isodon-colour) were not trapped.

The back hair is (3) $-4 \mathrm{~mm}$ long with (3) - 4 segments. The tip segment is long and at least $50 \%$ of the whole length of the hair (compare with the spring fur). The summer fur can easily be distinguished from other kinds of fur on the basis of the length of its back hair.

The belly hair is usually $2+1 \mathrm{~mm}$ long, seldom $2.5+1 \mathrm{~mm}$, with 3 $(2-4)$ segments. Some single hairs lack the pigment like the grey hairs on the back side.

$\mathrm{R}$ e s t $\mathrm{sta}$ ge s. In these individuals moulting has apparently stopped: there is no black pigment (or the pigment is, in a few individuals, sparse: partial rest stage) on the inner surface of the skin, although they are moulting individuals: e.g. winter fur on the back, spring fur on the belly. There is always a distinct difference beetwen long and short hair in some area of the fur.

\section{FEMALES}

\subsection{Increase in Growth and Maturation}

Both sexes are about equal size (Figs. 2 and 3) in late March, or the males are a little bigger. Then both begin to grow, but the females are smaller during the whole of April, because they are not yet mature. But in early May the matured and pregnant females are already higger than males. The females then seem to grow continuously; they grow especially fast in late April when they mature and in early May as they become visibly pregnant.

It is not always possible in late March to distinguish the sexes 
without section, even if the females as a rule have small teat spots on the belly side, but sometimes males also have such slight spots.

Uterus and vagina are still very small in March, but vagina grows in early April (when its length is $6-19 \mathrm{~mm}$, on an average $10 \mathrm{~mm}$ ) and begins to thicken $(\phi 1.5-2 \mathrm{~mm})$ and to twist resembling somewhat the penis. Uterus is still small, its arms are $2-3 \mathrm{~mm}$ long and $0.5-1.0 \mathrm{~mm}$ thick. The genitals remain in this condition to the end of April.

Judging by the appearance of embryos the females mature in late April - early May. In nature it is not until this time possible to hear the high squeaks which mark the meeting of two shrews. I have heard the first voices 7.V.66, 27.IV.67, 22.IV.68, 8.V.71 and 21.IV.72. According to Siivonen (1956) the rutting-time happens in South and Central Finland in late April and early May.

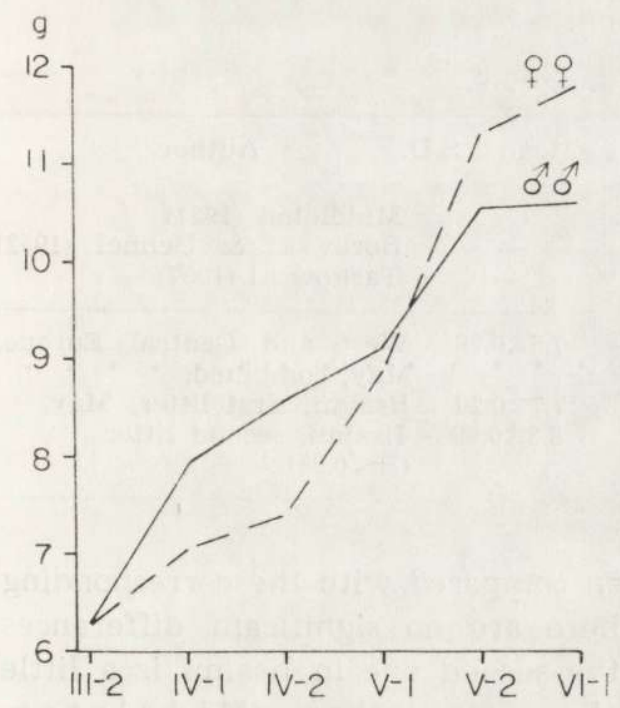

Fig. 2. Body weight 15.III.-15.VI.

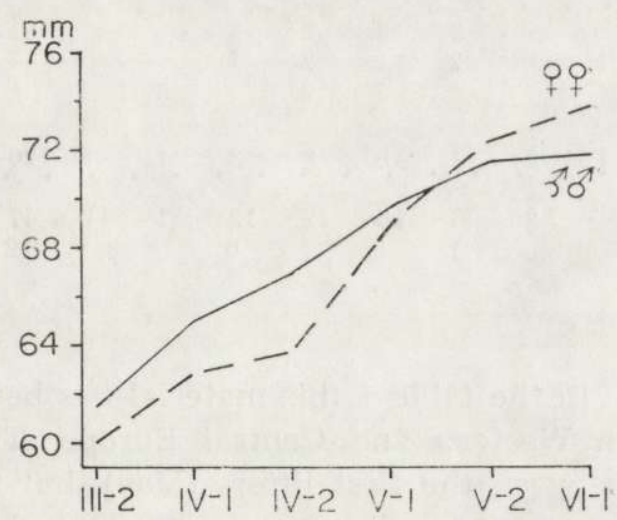

Fig. 3. Length of head and body 15.III.-15.VI.

Fifty per cent of the females caught during the first half of May. were visibly pregnant. The earliest of such individuals were trapped 30.IV.72 (the length of the embryos was $1.8 \mathrm{~mm}), 8 . V .71(2.5 \mathrm{~mm})$ and 11.V.68 $(3 \mathrm{~mm})$.

No lactating animal was trapped during the first half of May.

The embryos appear at the same time when the weather begins to warm up (see page 445): the mean temperature rises to $+5^{\circ} \mathrm{C}$ in Kuopio usually $5 . \mathrm{V}$. and there is only a little snow left. 
Only three individuals of the 53 females trapped during the second half of May were not pregnant and/or lactating. The first litter is born during this period: the first lactating animals were trapped 18.-30.V. The date of birth usually seems to fall on the last week of May, but possibly there are differences according to the habitat (e.g. snow usually melts slower in forests).

Approximately every third (16 from 46) females became pregnant immediately after parturition (postpartum oestrus): these lactating (great teats, big milk glandular tissue) animals already have new small visiable embryos in late May and early June.

All 37 females trapped during the first half of June were lactating and/or pregnant. The first juveniles (born in May) were trapped 6.VI.61 (Helsinki) and 12.VI.58 (Lammi) (S k a rén \& K a i k u a lo, 1966).

Table 1

Litter size in spring.

\begin{tabular}{|c|c|c|c|c|c|c|c|c|c|c|}
\hline 4 & 5 & 6 & 7 & 8 & 9 & 10 & 11 & $\mathrm{n}$ & Mean \pm S.D & Author \\
\hline \multirow{3}{*}{1} & & 2 & 4 & 3 & 2 & & & 11 & - & \multirow{3}{*}{$\begin{array}{l}\text { Middleton (1931) } \\
\text { Borowski \& Dehnel (1952) } \\
\text { Tarkowski (1957) }\end{array}$} \\
\hline & & 2 & 1 & 2 & 1 & & & 7 & - & \\
\hline & & & 3 & 3 & & 1 & 1 & 8 & - & \\
\hline \multirow[t]{2}{*}{1} & & 4 & 8 & 8 & 3 & 1 & 1 & 26 & $7.5 \pm 0.28$ & \multirow{2}{*}{$\begin{array}{l}\text { West and Central Europe, } \\
\text { May, combined. } \\
\text { Iisalmi, first litter, May. } \\
\text { Iisalmi, second litter } \\
(\mathrm{P}<0.05) \text {. }\end{array}$} \\
\hline & 2 & $\begin{array}{l}6 \\
1\end{array}$ & $\begin{array}{r}13 \\
3\end{array}$ & $\begin{array}{r}12 \\
1\end{array}$ & $\begin{array}{r}12 \\
6\end{array}$ & 1 & $\begin{array}{l}1 \\
1\end{array}$ & $\begin{array}{l}47 \\
12\end{array}$ & $\begin{array}{l}7.7 \pm 0.29 \\
8.3 \pm 0.08\end{array}$ & \\
\hline
\end{tabular}

In the table 1 this material has been compared with the corresponding in Western and Central Europe. There are no significant differences between the first litters (May), but the second one in Iisalmi is a little larger. According to many Central European authors (M iddleton, 1931; Brambell, 1935; Borowski \& Dehnel, 1952; Tark ow s ki, 1957; and others) the first litter of the common shrew is the largest.

\subsection{Moult of Females}

All females trapped in late March had winter fur (Table 2), although the moulting of males already had begun. Also Borowski (1968) points that the females moult later.

Most females have the winter fur during the whole of April. However, some of them begin to moult it directly to summer fur and only a few 
to spring fur. In both cases belly side changes first. If there is pigment on it and the new hair has not grown yet, it is impossible to say whether it is summer or spring fur that is coming. In the table such (rare) females have, however, been listed among the former, because females only very seldom seem to get spring fur: there are only three females with pure spring fur among 175 females trapped in spring. They differ from males clearly (Table 2).

Table 2

Different kinds of fur in spring.

\begin{tabular}{|c|c|c|c|c|c|c|c|c|c|c|c|c|}
\hline \multirow{3}{*}{ * } & \multicolumn{4}{|c|}{ 15. III $-31 . \mathrm{III}$} & \multicolumn{4}{|c|}{ 1. IV $-14 . \mathrm{IV}$} & \multicolumn{4}{|c|}{ 15. IV $-30 . \mathrm{IV}$} \\
\hline & \multicolumn{2}{|c|}{ Males } & \multicolumn{2}{|c|}{ Females } & \multicolumn{2}{|c|}{ Males } & \multicolumn{2}{|c|}{ Fenales } & \multicolumn{2}{|c|}{ Males } & \multicolumn{2}{|c|}{ Females } \\
\hline & $\mathrm{n}$ & ${ }_{0}^{0}$ & $\mathrm{n}$ & $\%$ & $\mathrm{n}$ & $\%$ & $\mathrm{n}$ & $\%$ & $\mathrm{n}$ & $\%$ & $\mathrm{n}$ & $\%$ \\
\hline 1 & 15 & 71.4 & 14 & 100 & 5 & 9.8 & 18 & 78.3 & 4 & 8.0 & 13 & 43.3 \\
\hline 2 & 4 & 19.0 & - & - & 19 & 37.3 & 2 & 8.7 & - & - & - & - \\
\hline 3 & -- & - & - & - & 6 & 11.8 & - & - & 9 & 18.0 & 1 & 3.3 \\
\hline 4 & - & - & - & - & - & - & 2 & 8.7 & - & - & 5 & 16.7 \\
\hline 5 & - & - & - & - & - & - & - & - & - & - & 10 & 33.3 \\
\hline 6 & 2 & 9.5 & - & - & 21 & 41.2 & 1 & 4.3 & 36 & 72.0 & 1 & 3.3 \\
\hline 7 & - & - & - & - & - & - & - & - & - & - & - & - \\
\hline 8 & - & - & - & - & - & - & - & - & 1 & 2.0 & - & - \\
\hline \multirow[t]{2}{*}{9} & - & - & - & $\cdots$ & - & - & 一 & - & - & - & - & - \\
\hline & 21 & & 14 & & 51 & & 23 & & 50 & & 30 & \\
\hline
\end{tabular}

\begin{tabular}{|c|c|c|c|c|c|c|c|c|c|c|c|c|}
\hline \multirow{3}{*}{ * } & \multicolumn{4}{|c|}{$1 . \mathrm{V}-14 . \mathrm{V}$} & \multicolumn{4}{|c|}{$15 . \mathrm{V}-31 . \mathrm{V}$} & \multicolumn{4}{|c|}{ 1.VI-15.V } \\
\hline & \multicolumn{2}{|c|}{ Males } & \multicolumn{2}{|c|}{ Females } & \multicolumn{2}{|c|}{ Males } & \multicolumn{2}{|c|}{ Females } & \multicolumn{2}{|c|}{ Viales } & \multicolumn{2}{|c|}{ Females } \\
\hline & & & & & $\mathrm{n}$ & $\%$ & $\mathrm{n}$ & $\%$ & $\mathrm{n}$ & $\%$ & $\mathrm{n}$ & $\%$ \\
\hline 1 & 1 & 2.6 & 2 & 5.6 & - & - & 一 & - & - & - & - & - \\
\hline 2 & 7 & 18.4 & - & - & - & - & - & - & - & - & - & - \\
\hline 3 & 12 & 31.6 & 1 & 3.8 & - & - & - & - & - & - & - & - \\
\hline 4 & - & - & 10 & 38.4 & 1 & 1.7 & 9 & 17.6 & - & - & - & \\
\hline 5 & - & - & 8 & 30.8 & - & - & - & - & - & - & - & - \\
\hline 6 & 16 & 42.1 & - & - & 36 & 61.0 & 1 & 2.0 & 3 & 5.5 & - & - \\
\hline 7 & 2 & 5.3 & 一 & - & 3 & 5.1 & - & - & 8 & 14.5 & - & - \\
\hline 8 & - & - & - & - & 13 & 22.0 & 2 & 3.9 & 6 & 10.9 & - & - \\
\hline \multirow[t]{2}{*}{9} & - & - & 5 & 19.2 & 6 & 10.2 & 39 & 76.5 & 38 & 69.1 & 31 & 100 \\
\hline & 38 & & 26 & & 59 & & 51 & & 55 & & 31 & \\
\hline
\end{tabular}

* Fur type: 1-winter fur, 2-spring moult I with pigment, 3 -the same in rest stage, 4 - winter fur changing into summer fur, with pigment, 5 - the same in rest stage, 6-spring fur, 7 -spring moult II with pigment, 8 - the same in rest stage, 9 - summer fur.

The rest stages are rather common in late April and early May; as a rule, the back and the caudal belly side have winter fur, the rest of the belly side has summer fur.

The main moulting period of females is the first half of May; nearly all of them get the summer fur outright, considerably before the males. 
The last females with pure winter fur were trapped 3.V.69 and 3.V.72 and the first one with pure summer fur 12.V.68 and 11.V.72. Moulting was perceptibly over before parturition, viz. when embryos were about $7 \mathrm{~mm}$ long (Fig. 4); at the utmost there were small spots of pigment left on the back (parturition seems to happen when the embryos are about $14 \mathrm{~mm}$ long).

During the second half of May the bulk of the females and in June all of them already had summer fur. The long winter fur loosens by wearing away (or e.g. by strooking it with finger) when the dense summer fur on the bases of the winter hairs is already nearly grown-up.

\section{MALES}

\subsection{Increase in Growth and Maturation}

Some males may begin to grow as early as late March, but the main spring jump in growth happens during the first week of April at the same time when the animals attain maturity and the first spring moult is taking place (Figs. 2 and 3 ).

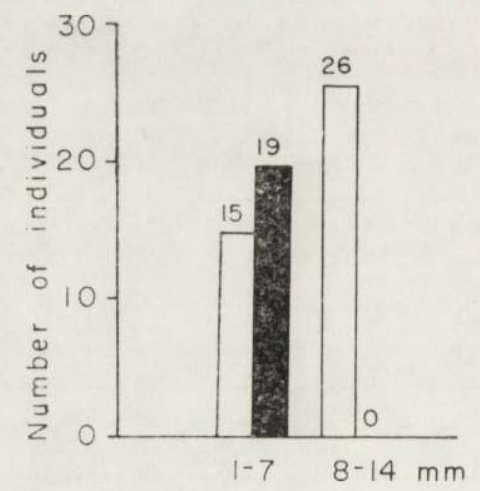

Fig. 4. Length of the embryos and the pigment in May: moulting is ended during the first half of pregnancy. Black column: skin with pigment, white: no pigment.

Then the males grow continuously and are both heavier and longer $(P<0.01)$ than the females in early April. But in May the size of the latter exceeds that of the males. The maximum size of the males is recorded in late May; the difference in June is not significant. According to $\mathrm{Schubarth}$ (1958) the males in North Germany are bigger than females as early as in March, but otherwise this results are very similar, e.g. the males were smaller in May. 
In winter (1.X.-14.III.) the testes are very small, $1.0-1.5 \mathrm{~mm}$ long $(n=66)$, but they begin to grow in late March (Table 3 ). All the males mature during the first of April at the latest, about three weeks earlier than females. Penis become full-grown and testes descend when the first spring moult is finished. In spring 1971 the first male with descensus was trapped 5.IV. and it had nearly pure spring fur. Before it (1.-4.IV.) I got five males with no descensus and all of them were still moulting. 10.IV.68 I got an exceptional male still in winter fur and ist testes had not yet descended like most other males at that time. But the resting stages of fur change do not block maturation. According to $\mathrm{Br}$ a m be 11 (1935) the first mature males were trapped in England 13.III, and Crowcroft (1957) writes that some had descensus as early as in February - March.

Table 3

Length of testis.

\begin{tabular}{lcccc}
\hline & Minimum & Maximum & Mean \pm S.D. & $\mathrm{n}$ \\
\hline 15.-31.III & 1.5 & 6.5 & $4.0 \pm 0.31$ & 21 \\
1.-14.IV & 3.5 & 7.5 & $6.3 \pm 0.12$ & 51 \\
15.-30.IV & 5.5 & 8.0 & $7.2 \pm 0.09$ & 54 \\
1.-14.V & 6.0 & 8.0 & $7.3 \pm 0.07$ & 57 \\
15.-31.V & 6.0 & 8.0 & $7.1 \pm 0.07$ & 37 \\
1.-15.VI & 6.5 & 8.0 & $7.5 \pm 0.07$ & 35 \\
\hline
\end{tabular}

All the males are mature at least from 15.IV. on and testis remains over $7 \mathrm{~mm}$ long about 1.5 months (Table 3). It grows a little in late May and early June $(P<0.01)$ and this phenomenon may be in connexion with the spring moult II of the postpartum oestrus of females.

\subsection{Moult of Males}

Moulting may begin in late May (Table 2), but usually it starts in early April. The males have normally two moults in spring. The first one is rapid: during about one week in late March - early April the long winter fur changes into spring fur (Fig. $5 \mathrm{~A}$ ). Moulting begins at least in some males around the side-glands. Then the black pigment appears on the flesh side of the belly; it disappears either regularly from the front backwards or so that the last pigment is visible in the middle of the belly side. After this the front part of the back, the sides and the rest of the back side moult. A new, dense, light and a little shorter spring fur appears on the base of the old winter hair that easily loosens. The 
first males in pure spring fur were trapped 2.IV.70, 6.IV.71 and 27.III.72.

In approximately one fifth of the males the spring moult I is interrupted; the rest stage lasts till May. These animals usually have spring fur on the belly side and winter fur on the back. The moult makes a new start in May (at least during its second week) and these animals directly
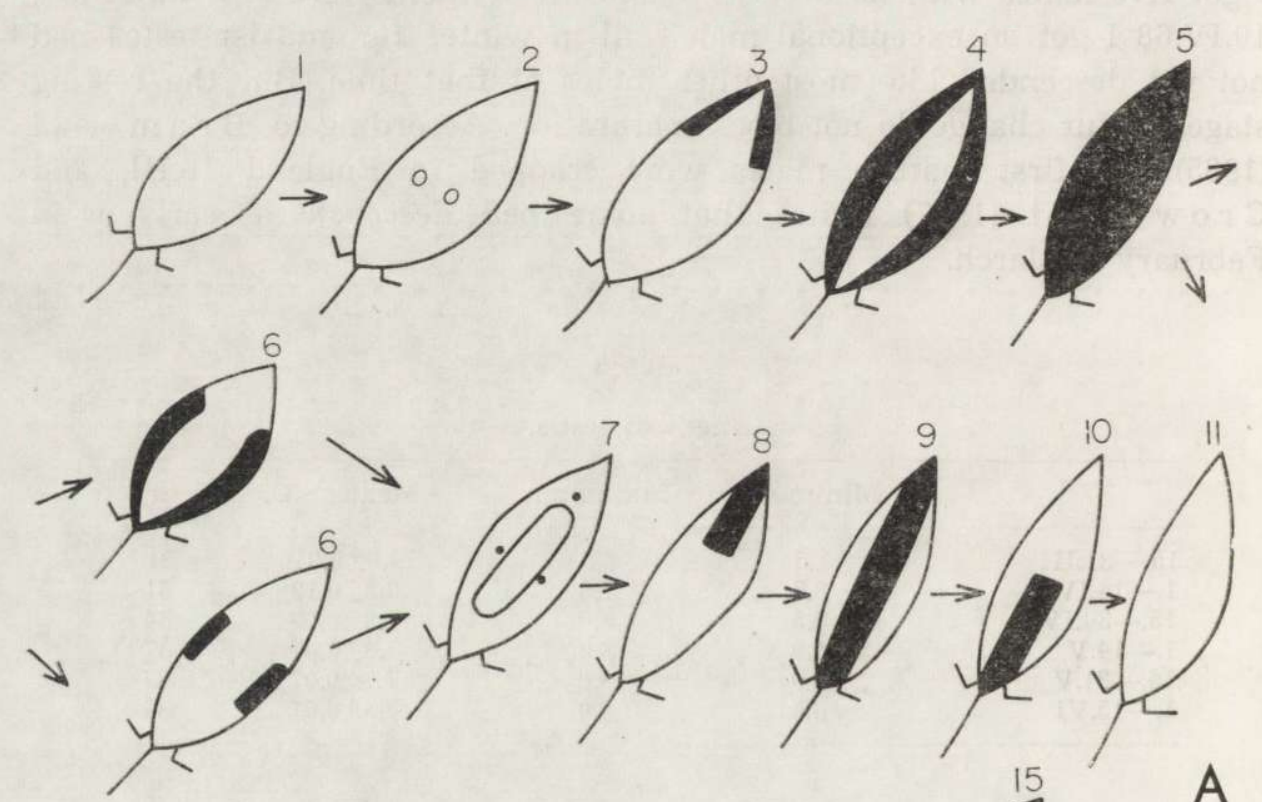

A
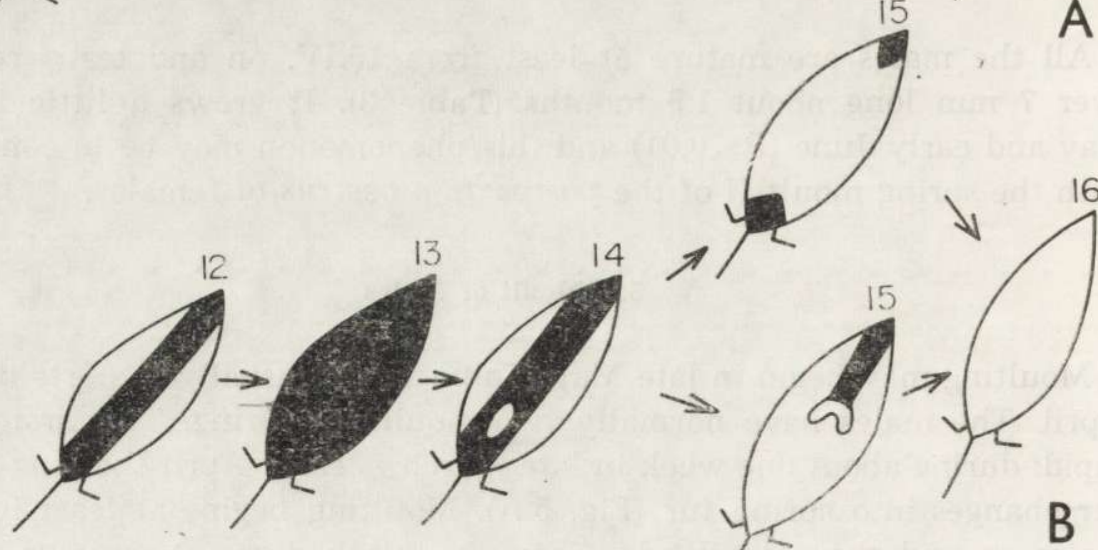

Fig. 5 A. Spring moult I. The pigment appears on the flesh side of the skin around the side-glands, then it spreads under the throat and backwards over the whole skin. The new fur first appears on the belly side and last on the rump.

Fig. 5 B. Spring moult II. The pigment first appears on the back side that normally gets summer fur before the belly side. 
get the summer fur, but there may be a second rest stage, too. In it the spring fur covers the belly side and the summer fur the back; such males are fairly common in late May and early June.

The difference between males and females is clearly visible in late April: most males have spring fur, females winter fur (Table 2). Nevertheless, the last individual of both sexes in pure winter fur were trapped in early May, the last male 9.V.69, but such individuals are exceptional.

The second spring moult (spring fur changes to summer fur) may sometimes start in about the middle of May (the first individuals 12.-13.V.68 and 14.V.71), but most males are either in spring fur or in rest stage in May. Only six males in pure summer fur were trapped in May, the first ones 19.V.66, 31.V.68, 20.V.69 and 26.V.71. The second spring moult mainly happens in early June - two months later than the first one. The first litter leaves the nest only a little later.

At the beginning of the spring moult II (Fig. 5 B) the pigment first appears on the back side and immediately after this on the belly side. Then very soon the dense summer fur begins to grow visible from the base of spring hair. Sometimes the new fur is visible on the back when there is not yet pigment on the belly side: then the back changes before the belly. In some individuals moulting may begin on the back, but, nevertheless, the summer fur may first appear on the belly side (the caudal parts of which change last). Then the middle of the back is next and after it the rest of the back changes.

This last spring moult may also be interrupted by rest stage: e.g. there may be spring fur on the belly side and summer fur on the back, and no pigment.

The spring moult II may thus happen in somewhat different ways. In all cases, however, the pigment first appears on the back and this happens when the thermal meteorological summer begins.

\section{SEX RATIO}

During the winter months (November-March) sex ratio has been fairiy even (Table 4): 106 males - 121 females does not significantly differ from the $1: 1$ ratio.

But there is a clear-cut change in early April: more males were trapped; at the same time they attain maturity. In the whole spring material (1.IV.-15.V.) there are more males $(P<0.01)$. But if the same spring material is arranged into fortnight periods (Table 4), the last half of May differs $(P<0.02)$ from the rest of the spring: the number of females increases and the ratio is again the same $(1: 1)$ as in winter and which is 
apparently the real one. However, again in June clearly more males were trapped.

The increasing activity of females in late May seems to be in connexion with the birth of the first litter and the postpartum oestrus. It is at least difficult to see any reason that would decrease the activity of males during a period when there are many females running in oestrus.

B rambell already (1935) knew the majority of males in spring, but he supposed that during oestrus period the females would be less active. Apparently, however, this is not a valid explanation, because the females »disappear " as early as early April, nearly a month before their first oestrus period. I think $\mathrm{Crow}$ croft (1957) is right when writing that it is the increase in the activity of the males which causes the illusion of a decrease in that of the females «. In his study concerning marked animals B u ckner (1969) concluded that the females remained

Table 4

Sex ratio.

\begin{tabular}{|c|c|c|c|c|c|c|c|c|c|c|c|c|c|c|}
\hline & \multicolumn{2}{|c|}{$\mathrm{X}-\mathrm{III}$} & \multicolumn{2}{|c|}{ 1.-14.IV } & \multicolumn{2}{|c|}{ 15. $-30 . \mathrm{IV}$} & \multicolumn{2}{|c|}{ 1.- $-14 . \mathrm{V}$} & \multicolumn{2}{|c|}{$15 .-31 . \mathrm{V}$} & \multicolumn{2}{|c|}{ 1.-15.VI } & \multicolumn{2}{|c|}{ 1.IV.-.15.VI } \\
\hline & $\mathrm{n}$ & $\%$ & $\mathrm{n}$ & $\%$ & $\mathrm{n}$ & $\%$ & $\mathrm{n}$ & $\%$ & $\mathrm{n}$ & $\%$ & $\mathrm{n}$ & $\%$ & $\mathrm{n}$ & $\%$ \\
\hline Males & 106 & 46.7 & 56 & 70.0 & 66 & 63.5 & 65 & 66.3 & 74 & 55.2 & 64 & 62.7 & 325 & 62.7 \\
\hline Females & 121 & 53.3 & 24 & 30.0 & 38 & 36.5 & 33 & 33.7 & 60 & 44.8 & 38 & 37.3 & 193 & 37.3 \\
\hline $\mathrm{n}$ & 227 & & 80 & & 104 & & 98 & & 134 & & 102 & & 518 & \\
\hline
\end{tabular}

Table 5

Sex ratio in winter (individuals).

\begin{tabular}{lcccc}
\hline & $1968-69$ & $1969-70$ & $1970-71$ & $1971-72$ \\
\hline Viales & 32 & 9 & 16 & 33 \\
Females & 37 & 11 & 14 & 41 \\
\hline
\end{tabular}

in spring at the same territory where they were in autumn, but males abandoned their home ranges and wandered widely: this is apparently an effective way to certify the reproduction during the years of low populations.

Borowski \& Dehnel (1952) and Pucek (1959) have noted a variation in sex ratio during different years. I did not observe any; see Table 5 .

\section{DISCUSSION}

Taken as a whole the results of this study of moulting agree with those of Borowski (1968). Thus the rest stages are common in Fin- 
land, too, but it is not easy to see reasons for them. Most of such animals were trapped during 15.IV.-14.V. (Table 6). There are as many rest stages in 1971 as in 1972 and these years differ significantly $(P<0.01)$ from the years 1968 and 1970. It is not possible to see a positive correlation with e.g. the earliness of spring: it came late in 1971 and early in 1968 and 1972. Every year, however, there have been both cold and warm periods in spring, so it is possible that if such a cold period happens at the point when moulting is starting it interrupts the process and causes the rest stage.

But it is not sure that the temperature would directly cause the onset of moulting. Thus it is always in late March - early April irrespective of the earliness or delay of spring; the snow cover is often still thick at that moment, thus effectively insulating the warm temperature near the surface of the soil where shrews mainly live. Moreover, at least the autumn moult may start in the cage in spite of the high temperature ( $\mathrm{Skarén} \& \mathrm{Kaikusalo,1966).} \mathrm{But} \mathrm{in} \mathrm{every} \mathrm{case} \mathrm{the} \mathrm{moult} \mathrm{begins}$ in Finland about a month later than in England ( $\mathrm{Cr}$ ow c r of t, 1957) and in Poland (B or ow ski, 1968).

Table 6

The number of rest stages.

\begin{tabular}{llllll}
\hline & 1968 & 1970 & 1971 & \multicolumn{1}{c}{1972} & $\mathrm{n}$ \\
\hline Rest stages & $10(38.5 \%)$ & $7(58.3 \%)$ & $5(20.0 \%)$ & $13(19.7 \%)$ & $35(27.0 \%)$ \\
Others & 16 & 5 & 20 & 53 & 94 \\
n & 26 & 12 & 25 & 66 & 129 \\
\hline
\end{tabular}

Because the body begins to grow when moulting starts, many authors (e.g. Niethammer, 1956) have assumed that the improving food conditions cause both phenomena. This is hardly true. Firstly, there is still much snow and it seems unlikely that the activity of invertebrates would suddenly increase at this time. Secondly, it is difficult to understand why this increase, if it really happens, does, not affect the females, which begin to moult nearly one month later: they presumably eat the same food.

Because the amount of light every spring uniformly increases, it could be the increased hormonal activity that causes these phenomena. But the results with caged animals (B orow ski, 1964) are very conflicting: sometimes light seems to have an effect, sometimes not.

It seems that the causes of moulting are not yet clear. Also the assuming of Borowski (1952) that different microclimatic conditions in different habitats would cause moulting needs further defining, e.g. the 
differences in food conditions in different habitats should be investigated. It ought also to be remembered that the males are widely wandering from one habitat to another in spring.

In Northern Lapland the animals probably moult later than in Central Finland. There are two pure spring furs in my collections from Kilpisjärvi, late June. The midsummer moulting mentioned by some authors (O gnev, 1928; Stein, 1954) which is not known to many other authors is probably the late spring moult II. Thus I trapped 1.-5.VII.73 some males in Finnmark, North Norway, with pigment of the second spring moult.

Possibly the known chromosomal polymorphism in Sorex araneus (M e y la n, 1965, Fredga, 1973) causes physiological differences in different parts of Europe. Thus C r ow c r of t (1957) mentions that many females are moulting when they suckle their first litter; in the present material all suckling females already had pure summer fur. The same author also points that the colour of summer and winter fur is the same - in Finland there is a clear difference especially on the belly side. Further, the white spots near ears are common in England but lacking in Finland.

The advantage of this long spring moulting seems to be, as Borowski (1968) points, adapting to long and cool springs. If this is true, there should be differences between maritime and continental climates: spring in the latter is short. New data from e.g. Central Siberia are needed.

One may think that this situation would be worse for females that get the thin summer fur early in May; there are often night frosts and snowing in late May. Apparently the thick fat milk grandular tissue helps to keep them warm.

Acknowledgements: This study has been aided by grants from Suomen Kulttuurirahasto. I am also indebted to Mrs. Ritva Antikainen, who has kindly checked the English of my manuscript.

\section{REFERENCES}

1. B a u e r K., 1960: Die Säugetiere des Neusiedlersee-Gebietes (Ósterreich). Bonn. zool. Beitr., 11, 2-4: $141-344$.

2. Borowski S., 1952: Sezonowa zmiana uwlosienia u Soricidae. Annls Univ. M. Curie-Skłodowska, C 7, 2: 65-117.

3. Borowski S., 1964: Moult of shrews (Sorex L.) under laboratory conditions. Acta theriol., 8, 8: 125-135.

4. Borowski S., 1968: On the moult in the common shrew. Ibidem, 13, 30: $483-498$.

5. Borowski S. \& Dehnel A., 1952: Angaben zur Biologie der Soricidae. Anrils Univ. M. Curie-Skłodowska, C 7, 6: 305-448. 
6. Brambel1 F. W. R., 1935: Reproduction in the common shrew. Proc. Soc. Zool. Lond. B, 225: 1-63.

7. Buckner C. H., 1969: Some aspects of the population ecology of the common shrew, Sorex araneus, near Oxford, England. J. Mammal. 50, 2: 326-332.

8. Crowcroft P., 1957: The life of the shrew. Max Reinhardt. 1-166. London.

9. Fredga K., 1973: Chromosome studies of the common shrew (Sorex araneus). in Sweden. Hereditas 73: 153-157.

10. M e y la n A., 1965: Repartition geographique des races chromosomiques de Sorex araneus L. en Europe (Mamm.-Insectivora). Rev. suisse Zool., 72: 636-646.

11. Middleton A. D., 1931: A contribution to the biology of the common shrew, Sorex araneus Linnaeus. Proc. zool. Soc. Lond., 1: 133-143.

12. Niethammer J., 1956: Das Gewicht der Waldspitzmaus, Sorex arraneus Linné, 1758, im Jahreslauf. Säugetierfcdl. Mitt. 4, 4: 160-165.

13. Ognev S. I., 1928: Mammals of eastern Europe and northern Asia. Israel Program for Scientific Translations 1: 1-487. Jerusalem 1962.

14. Pucek Z., 1959: Some biological aspects of the sex-ratio in the common shrew (Sorex araneus araneus L.). Acta theriol., 3, 4: 43-73.

15. Schubart H., 1958: Zur Variabilität von Sorex araneus araneus L. Acta theriol., 2, 9: 175-202.

16. Siivonen L., 1954: Uber die Grössenvariationen der Säugetiere und die Sorex macropygmaeus Mill. - Frage in Fennskandien. Ann. Acad. Scient. Fennicae, A IV, 21: 1-24.

17. Si ivonen L., 1965: Suuri nisäkäskirja. Otava: 1-800. Helsinki.

18. Skarén U., 1964: Variation in two shrews, Sorex unguiculatus Dobson and S. a. arraneus L. Ann. zool. Fennici 1: 94-124.

19. Skarén U. \& Kaikusalo A., 1966: Suomen pikkunisäkkäät. [Small mammals of Finland]. Otava: 1-227. Helsinki.

20. Spannhof L., 1952: Spitzmäuse. Die Neue Brehm-Bücherei: 1-44. Leipzig.

21. Ste in G.H.W., 1938: Biologische Studien an deutschen Kleinsäugern. Archiv, f. Natugesch., b 7: $477-513$.

22. Stein G. H. W., 1954: Materialen zum Haarwechsel deutscher Insectivoren. Mitt. zool. Mus. Berlin, 30: 12-34.

23. Tarkowski A. K., 1957: Studies on reproduction and prenatal mortality of the common shrew (Sorex araneus L.). Part II. Reproduction under natural conditions. Annls Univ. M. Curie-Skłodowska, C 10, 8:: 177-244.

24. Wolska J., 1952: Die Entwicklung des Geschlechtsapparates von Sorex. araneus L. in Lebenszyklus (I). Ibidem, C 7, 8: 495-539.

Accepted, August 10, 1973.

74300 Sonkajärvi,

Finland. 


\section{Uolevi SKAREN}

\section{LINKA WIOSENNA I POCZĄTEK SEZONU ROZRODU U RYJÓWKI AKSAMITNEJ W SRODKOWEJ FINLANDII}

\section{Streszczenie}

Materiał $(\mathrm{N}=746)$ zbierano w środkowej Finlandii zimą i na wiosnę. Linka ryjówki aksamitnej $\mathrm{w}$ tym regionie jest zjawiskiem złożonym, trwa około 2 miesiące i wydaje się być, przynajmniej częściowo związana z działaniem hormonów płciowych.

S a m ce zaczynają linieć w końcu marca lub początku kwietnia, czyli jeszcze przed nastaniem wiosny. Proces ten zachodzi szybko i już po kilku dniach mają one futerko wiosenne a równocześnie stają się dojrzałe płciowo. Jednakże dość często linka z niewytłumaczonych przyczyn zostaje przerwana, przy czym częstość tego zjawiska jest różna w różnych latach. Futro wiosenne zmienia się na letnie w dwa miesiące później, kiedy nadchodzi termiczne lato.

U s a mi c linka wiosenna pierwsza, występuje rzadko. $\mathrm{Z}$ reguły $\mathrm{w}$ końcu kwietnia - początku maja zmieniają one futerko zimowe na letnie. Zatem sierść letnia pojawia się u nich o 2-3 tygodnie wcześniej niż u samców. Linka wiosenna samic odbywa się przed początkiem rozrodu. Wielkość pierwszego miotu jest taka sama jak w zachodniej i środkowej Europie, natomiast miot drugi jest nieco mniejszy. Stosunek płci w zimie i wczesnym latem równa się $1: 1$ (subad.), zaś u przezimków łowiono więcej samców przez całą wiosnę z wyjątkiem końca maja kiedy to stosunek wynosil $1: 1$. 